\title{
A sikérfehérjéket nem tartalmazó (gluténmentes) termékek táplálkozási és technológiai minőségének fejlesztése
}

\author{
TÖMÖSKÖZI Sándor ${ }^{1}$, NÉMETH Renáta ${ }^{1}$, ROZNÁR Petra ${ }^{1}$, Denisse Bender ${ }^{2}$, JAKSICS Edina ${ }^{1}$, \\ TURÓCZI Fanni ${ }^{1}$, TÖRÖK Kitti ${ }^{1}$ és Regine SCHÖNLECHNER ${ }^{2}$ \\ ${ }^{1}$ BME Vegyészmérnöki és Biomérnöki Kar, Alkalmazott Biotechnológia és Élelmiszertudományi Tanszék, \\ 1111 Budapest, Szent Gellért tér 4. \\ ${ }^{2}$ Institute of Food Technology, Department of Food Science and Technology, BOKU-University of Natural \\ Resources and Life Sciences, Muthgasse 18, 1190 Vienna, Austria
}

\section{Bevezetés}

A cöliákia („lisztérzékenység”, „gluténérzékenység”) autoimmun-mediált emésztőrendszeri rendellenesség, amely a bélnyálkahártya károsodása miatt felszívódási problémákat okoz. Mindez a tápanyaghasznosulás romlásához, akár súlyos alultápláltsághoz is vezethet. A megbízható tudományos háttérrel végzett nemzetközi felmérések szerint globális átlagban a népesség 1-2\%-a érintett ebben a betegségben. Földrajzi területenként, országonként ez az arány jelentősen eltérhet. ${ }^{1,2}$ A betegség kialakulásáért az egyes gabonákban (búza, rozs, árpa) található tartalékfehérjék (glutén- vagy helyes magyar elnevezéssel sikérfehérjék) egyes csoportjai

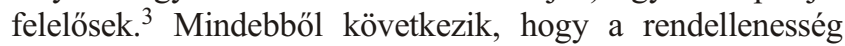
kezelésének egyetlen megbízható módja jelenleg a sikérfehérjéket tartalmazó élelmiszerek fogyasztásának elhagyása. A gluténmentes élelmiszer alapanyagok közül legfontosabbnak a kukoricát és a rizst tekinthetjük, de újabban az alternatív gabonák (köles, cirok, zab, stb.) és az ún. álgabonák (amaránt, hajdina, quinoa) növekvő mértékü hasznosítása is megfigyelhetö. Ez utóbbiak lassú, de egyértelmü terjedése részben a különböző anyagoknál különböző mértékben jelentkező táplálkozási előnyöknek (pl. kedvezőbb aminosav, lipid, rost, ásványi anyag vagy bioaktív komponens összetétel), részben a fogyasztói igények változásának, a választékbővítésnek köszönhető. ${ }^{4,5,6}$

A sikérfehérjék azonban - különösen a búza esetében alapvetően befolyásolják a gabonák, az örleményeikből készült tészták technológiai viselkedését és meghatározzák a sikértartalmú élelmiszerek (száraztészták, sütőipari termékek, stb). minőségének alakulását. A sikéralkotó fehérjefrakciók (glutelinek és prolaminok) és a gabonákban nagy mennyiségben jelen lévő keményítő ugyanis víz hozzáadásával és mechanikai munka befektetésével (dagasztással) jellegzetes, viszko-elasztikus tulajdonságokat mutató fehérje-keményítő mátrix kialakítására képesek. Alapvetően ezzel magyarázhatók a búzalisztből készült tészták és (kelesztést és sütést követően) a végtermékek jellegzetes, semmi máshoz nem hasonlítható

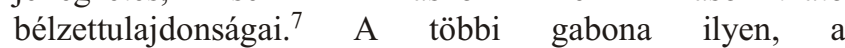
tartalékfehérjéknek tulajdonítható szerkezetalakító tulajdonsággal, nem, vagy csak kis mértékben rendelkezik. A rozs pl. tartalmaz ugyan a cöliákiások számára veszélyes gluténfehérjéket és sütőipari termékek is előállíthatók őrleményeiből, azonban a termékszerkezet alakításában a fehérjék mellett a táplálkozástani szempontból egyébként kedvező hatású egyes rostkomponensek, a pentozánok szerepe is jelentős. A gluténmentes alapanyagok technológiai tulajdonságai lényegesen eltérnek, örleményeikből víz hozzáadásával általában gyenge textúrájú, kevésbé elasztikus, ragadós tésztaszerkezet alakul ki, a hagyományos értelemben vett sütőipari tulajdonságaik rosszak. ${ }^{8} \mathrm{Az}$ eltérö technológiai viselkedés mellett, illetve részben ebből adódóan, a gluténmentes alapanyagok és termékek táplálkozási érték szempontjából is rendkívül változatos képet mutatnak. Főleg az olcsóbb élelmiszerek esetében, a homogenitás, az elfogadható technológiai tulajdonságok, a megfelelő érzékszervi jellemzők biztosítása érdekében hántolt termékek, finomított őrlemények forgalmazása és fogyasztása terjedt el. Ezen termékek jelentős részénél a fehérjék, ásványi anyagok, élelmi rostok, vitaminok, bioaktív összetevők, stb. mennyisége jelentősen elmaradhat az analóg búzaalapú termékek jellemző összetételétől. ${ }^{9,10}$

A fizikai-kémiai, reológia és állagbeli tulajdonságok javításának jelenleg általánosnak tekinthető módja a megfelelő adalék- és segédanyagok (pl. hidrokolloidok, emulgeátorok, fehérjeizolátumok, módosított keményítők stb.) és különböző eljárások (kovászos technika, enzimes vagy magasnyomású kezelések, stb.), vagy ezek kombinációjának alkalmazása. ${ }^{10,11}$ A tápérték növelésének lehetséges módja az alapanyagok (pl. hüvelyesek és gabonák) komplettálása, magasabb vagy akár teljes kiőrlésű őrlemények alkalmazása, illetve a limitáló komponensekkel történő kiegészítés, adagolás. Azonban ez utóbbi megoldások jelentősen és a magasabb kiőrlésü termékek esetében kifejezetten hátrányosan befolyásolják a termékek technológiai és érzékszervi sajátságait. ${ }^{11,12}$ Éppen ezért a jelen kutatás és termékfejlesztés iránya olyan megoldások keresése, melyek segítségével a tápérték és a technológiai és érzékszervi tulajdonságok javítása egyaránt lehetséges. A teljes, vagy magasabb kiőrlésü malomipari termék egészségügyi előnyei többek között a magasabb rost, lipid, ásványi anyag, bioaktív komponenstartalomnak tulajdoníthatók. A gabonarostok általában nagyobb mennyiségben tartalmaznak nem keményítő szénhidrátokat, 
pentozánokat, melyek meghatározó képviselői az arabinoxilánok (AX). Az AX molekulák elágazó heteropolimerek, melyben $\beta$-D-xilopiranozil monomerekből álló gerinchez kapcsolódnak $\alpha$-L-arabinofuranozil csoportok. A pentozán polimerek az alapanyagtól függő mértékben ferulasavat is tartalmaznak, melyek oxidációjával keresztkötések jöhetek létre. Az AX molekulák méretét és fizikai-kémiai tulajdonságait (oldhatóság, vízfelvétel, viszkozitás, tészták elaszticitása, stb.) értelemszerüen az $\mathrm{A} / \mathrm{X}$ arány, illetve a molekulák oxidációs állapota (a keresztkötések száma) alapvetően befolyásolja. ${ }^{13}$ Fentiekböl következik, hogy az AX polimerek oxidációs állapotának kémiai vagy enzimes úton történő megváltoztatásával a molekulák mérete és tulajdonságai célzott módon befolyásolhatók. Élelmiszerbiztonsági szempontok miatt értelemszerüen az enzimes kezelés, pl. oxidáz vagy lakkáz enzimek alkalmazása kívánatos. ${ }^{14}$ Ez azzal az előnnyel is jár, hogy a megfelelően kiválasztott, illetve módosított sejttenyészet (élesztő) alkalmazásával, az enzimkatalízis segítségével lejátszódó reakciók a fermentációs folyamatokba (kelesztés, kovászos technológia) beépíthetők. A megfelelően szabályozott oxidációval, a ferulasav-keresztkötések számának növelésével elméletileg akár olyan szénhidrát polimer hálózat is kialakítható (1. ábra), amely legalább részlegesen alkalmas lehet a gluténmentes termékekből hiányzó sikérfehérje háló helyettesítésére, és így a hidratált tésztamátrix reológiai tulajdonságainak javítására. ${ }^{15}$

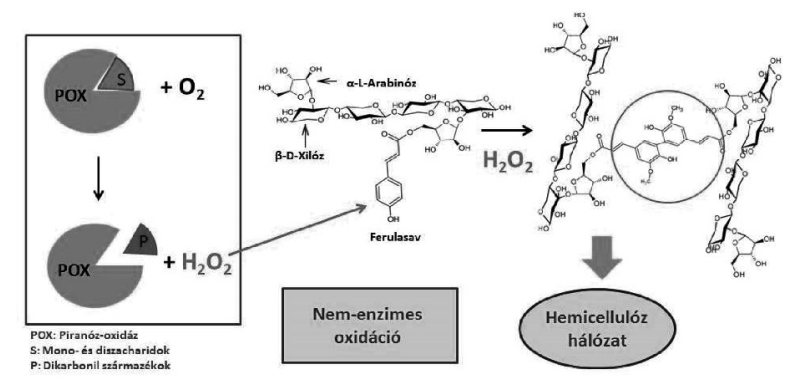

1. ábra Az arabinoxilán polimer hálózat kialakulásának egy lehetősége

Kutatómunkánkban -a fent vázolt gondolatmenet alapjángluténmentes őrleményekből készült tésztamátrixok viszko-elasztikus tulajdonságának módosítási lehetőségeit vizsgáltuk. Tanulmányoztuk a pentozántartalom, az enzimes kezelés és ezek kombinált alkalmazásának hatását a tészták reológiai tulajdonságának alakulására.

\section{Anyagok és módszerek}

A kísérletben gluténmentes alapanyagként piaci forrásból származó Goldhirse (Ausztria) márkanevü szemes kölesből készült finom (fehér) lisztet és teljes őrleményt használtunk. $\mathrm{Az}$ alapanyagot a Debreceni Egyetem Nyíregyházi Kutatóintézete bocsátotta rendelkezésünkre. Az őrlemények szénhidrátösszetételének módosításához a partner intézményünk (Universitiy of Natural Resources and Life Sciences, BOKU, Bécs, Ausztria) által előállított és közös munkával részletesen jellemzett arabinoxilán extraktumot használtunk. ${ }^{16,17} \mathrm{Az}$ enzimes kezelést a szintén a BOKU kutatói által izolált piranóz-oxidáz enzimmel (44 U/ml) végeztük, az enzimadagolás mennyiségét $(20 \mu \mathrm{l})$ előzetes kísérletekben optimáltuk. ${ }^{18} \mathrm{~A}$ minták kémiai összetételét szabványos módszerekkel határoztuk meg. A nedvességtartalmat szárítószekrényes eljárással határoztuk meg (MSZ EN ISO 719:2009, ICC Nr. 110/1), a hamutartalom méréséhez izzítókemencés módszert alkalmaztunk (MSZ EN ISO 2171:2010). A minták nyersfehérje tartalmát Dumas módszerrel (ISO/TC34/WG 19) mértük, FP-528 (Leco, Saint-Joseph, USA) típusú nitrogén analizátor használatával. A fehérjetartalom számításához az általános 6,25-ös faktort alkalmaztuk. A lisztek zsírtartalmának mérésérét az ICC Nr. 136 szabvány szerint végeztük, mely során félautomata Soxtec HT-1043/1046 (Tecator, Svédország) mérőberendezést használtunk. Ezen kívül meghatároztuk a lisztek élelmi rost tartalmát (oldható, oldhatatlan, teljes) az AOAC 991.43 és AACC 32-07 nemzetközi módszerek alapján, félautomata Fibertec 1023 (Foss-Tecator, Svédország) készülék alkalmazásával. A minták arabinoxilán tartalmát származékképzésen alapuló gázkromatográfiás eljárással határoztuk meg. ${ }^{19}$ A köleslisztekből víz hozzáadására kialakult tészta állagtulajdonságainak jellemzésére egy dagasztási elven alapuló komplex reológiai minősítésre alkalmas módszert és a Tanszékünk közremúködésével fejlesztett mérőberendezést, a micro-DoughLab-ot (Newport Scientific, Ausztrália) használtuk. Az alapmódszer hagyományosan lassan egy évszázada a búzaliszt minősítésére alkalmazott, nemzetközi szabványban rögzített eljárás. A kísérleteinkben használt méretcsökkentett változat alkalmas kis mennyiségü (4 g) őrlemény dagasztási tulajdonságainak vizsgálatára. Müködése során két darab, egymással szemben forgó Z-alakú karral dagasztjuk a tésztát és regisztráljuk a tésztakialakulás és ezt követően a folyamatos mechanikai munkabevitel során fellépő forgatónyomaték időbeli változását. ${ }^{20}$ Búzaliszt esetén a víz hozzáadásra hidratálódó sikérfehérjék által kialakított sikérhálózat viszko-elasztikus tulajdonságát vizsgáljuk. Gluténmentes alapanyagok esetén értelemszerűen a sikérfehérje-hálózat által meghatározott tulajdonságú tésztaszerkezet nem alakul ki. Azonban módszer- fejlesztésünk eredményei azt mutatják, hogy a dagasztásos méréstechnika gluténmentes alapanyag tésztáinak reológiai jellemzésére is alkalmazható. Kísérleteinkben a köleslisztekhez 1\% és 3\% (liszt tömegére vonatkoztatva) mennyiségben adagoltunk arabinoxilán extraktumot, 15 perces elökeverést alkalmazva. Az enzimes kezelések során 0,89 U piranóz-oxidázt (POX) használtunk. A méréseket 30 percig, standard keverési sebességgel, $30^{\circ} \mathrm{C}$-on végeztük.

$\mathrm{Az}$ eredményeket a szabványos módszerek esetében minimum két, a többi vizsgálatnál három párhuzamos mérés átlagával és szórásával adtuk meg. 


\section{Eredmények és értékelés}

\subsection{Alapanyagok összetétele}

A kölesőrlemények kémiai összetétele a gabonák malomipari feldolgozásánál megszokott képet mutatja. (1. táblázat) A fehérlisztek túlnyomórészt a mag tartaléktápanyagául szolgáló magbelsőt tartalmazzák, ennek megfelelően szárazanyagában legnagyobb mennyiségben a keményítő és a fehérje van jelen. A többi összetevő (hamu, rost, lipid) részaránya viszonylag csekély. A fehér kölesliszt esetében azonban meg kell említeni, hogy a többi finomított gabonaőrleményhez képest lipidtartalma viszonylag magasnak számít. A teljes örlemény lényegesen kedvezőbb tápanyagösszetétellel rendelkezik. Fehérjetartalma 5,7\%-kal magasabb, a lipid tartalom kétszeresére, a hamutartalom háromszorosára nőtt a fehérliszt megfelelő értékeihez hasonlítva. A kutatás alaphipotézise szempontjából azonban a nem keményítő szénhidrátok mennyiségének (élelmi rostalkotók) és összetételének alakulása is fontos információt hordoz. Az eredményekböl azt látjuk, hogy a táplálkozástani és technológiai funkcióknál egyaránt jelentősebb szerepet betöltő és reakcióképesebb oldható rosttartalom mindkét őrlemény esetében a meghatározási határt sem éri el. Emellett a teljes örlemény több, mint kétszer annyi nem oldható rostot tartalmaz, mint a fehérliszt. $\mathrm{Az}$ is egyértelmüen látszik az adatokból, hogy míg a teljes őrlemény nem keményítő szénhidrátjainak közel egyharmada arabinoxilán, addig a fehérlisztben ilyen komponens csak nagyon kis mennyiségben fordul elő.
Ezek az eredmények a szemtermés felépítésének és a malomipari feldolgozás műveleteinek ismeretében jól magyarázhatók. A teljes őrlemények tartalmazzák azokat a héjközeli és héjfrakciókat, melyek fiziológiai szerepe a magbelső (csíra és tartaléktápanyag) fizikai, kémiai és biológiai védelme. Ezért a magbelsőhöz képest lényegesen nagyobb mennyiségben tartalmaznak többek között nagy mechanikai szilárdságú rostkomponenseket, eltérö hidrofóbitású (összetett) lipidmolekulákat és biokémiai védelmet biztosító bioaktív anyagokat (enzimeket, antioxidánsokat, vitaminokat, stb.) Ezeknek az összetevőknek a humán táplálkozásban betöltött egészségtámogató szerepe jól ismert. Ugyanakkor az élelmiszerelőállítás során alkalmazott jellemző műveleteket és folyamatokat (pl. hidratáció, tésztaképződés, sütési tulajdonságok), vagyis az alapanyagok technológiai viselkedését és érzékszervi tulajdonságait a rostkomponensek jelentősen és általában negatív irányban befolyásolják. Ráadásul egyes magvak héjfrakcióiban antinutritív faktorok is előfordulnak, melyek eltávolítása kívánatos az élelmiszeripari feldolgozás előtt. Mindezek alapján érthető, hogy a korábbi évtizedekben meghatározóan olyan malomipari technológiák terjedtek el, amelyek a hántolás/őrlés/szeparálás müveleteinek kombinálásával részben vagy egészben eltávolítják a maghéj és a héjközeli, rostdús frakciókat. Jelen kutatás kérdésfeltevése tehát úgy is megfogalmazható: Hogyan lehet a táplálkozási értékben jelentkező elönyöket megtartani úgy, hogy az alapanyagok technológiai viselkedése és termékek élvezeti értéke is megfelelö legyen?

1. táblázat A köles őrlemények és az arabinoxilán extraktum kémiai összetétele

\begin{tabular}{lllll}
\hline & & $\begin{array}{l}\text { Fehér } \\
\text { kölesliszt }\end{array}$ & $\begin{array}{l}\text { Teljeskiörlésü } \\
\text { kölesliszt }\end{array}$ & $\begin{array}{l}\text { Arabinoxilán } \\
\text { izolátum }\end{array}$ \\
\hline Nedvességtartalom $(\%)$ & & $13,25 \pm 0,27$ & $11,00 \pm 0,22$ & $8,13 \pm 0,16$ \\
Fehérjetartalom (\%) & & $8,07 \pm 0,00$ & $13,73 \pm 0,20$ & $10,10 \pm 0,10$ \\
Zsírtartalom (\%) & & $1,65 \pm 0,10$ & $3,74 \pm 0,01$ & n.d. \\
Élelmi rost tartalom $(\%)$ & Oldható & $<\mathrm{LOQ}$ & $<\mathrm{LOQ}$ & n.d. \\
& Oldhatatlan & 1,71 & 3,80 & n.d. \\
& Összes & 1,71 & 3,80 & n.d. \\
Hamutartalom $(\%)$ & & $0,43 \pm 0,11$ & $1,25 \pm 0,11$ & $5,70 \pm 0,14$ \\
AX tartalom $(\%)$ & & $<\mathrm{LOQ}$ & $1,12 \pm 0,21$ & $35,43 \pm 3,5$ \\
\hline
\end{tabular}

Visszatérve a kölesőrlemények összetételi adataira, megállapítható, hogy az összes élelmi rosttartalom jelentősen eltér az irodalomban közölt értékektől. ${ }^{6}$ Sajnos a vizsgálataink során derült ki, hogy a kísérletsorozatba beállított köles részlegesen hántolt termék. Ugyanakkor úgy ítéltük meg, hogy a fö szakmai célkitüzés megvalósítását ez kevésbé befolyásolja. Így a méréstechnikák kidolgozásánál és az itt bemutatott kísérletsorozatban ezt az alapanyagot használtuk. A munka későbbi fázisában pedig már laboratóriumban elöállított kölesmintákat alkalmazunk.
Az osztrák partnerintézetünkben kifejlesztett izolálási módszerrel rozsból elöállított AX extraktum 35\%-os tisztaságú. A pentozán-polimer mellett fehérjét, hamut és glükózt (keményítőt) tartalmaz. Az AX izolálási és tisztítási lépések fejlesztésével lényegesen magasabb $\mathrm{AX}$ tartalmú készítmény is előállítható. Ez a munka kutatási programunk részeként jelenleg is folyik a bécsi partnernél. 


\subsection{Alapanyagok reológiai jellemzése}

A kölesőrleményekből vízadagolás és folyamatos mechanikai munkabevitel (dagasztás) következtében létrejövő tésztamátrix hidratációs folyamatát (tésztakialakulás fázisa) és stabilitásának alakulását a 2 . ábrán ('nincs adagolás' jelzésű minták) követhetjük nyomon. Látható, hogy a teljes őrleményből lényegesen gyorsabban, közelítőleg két perc alatt alakul ki tészta, melynek stabilitása is elfogadható. A tészta további mechanikai megmunkálás hatására ugyanis közel tíz percig stabil marad. Ezzel szemben a fehérliszt hidratációja lassabb, a maximális konzisztenciájú tésztaszerkezet eléréséhez közel tíz perc szükséges. A tészta stabilitása itt is kedvező, az ellágyulás csak a huszadik perc után indul meg. Jelentős különbség mutatkozik a különböző alapanyagokból készített tészták konzisztenciájában is. Jól látható, hogy a fehérlisztből erősebb tésztaszerkezet képződik, ennek maximális konzisztencia értéke majd 10 FU egységgel magasabb, mint a teljes őrlemény esetében.

Teljes kiőrlésű kölesliszt adagolási kísérlete

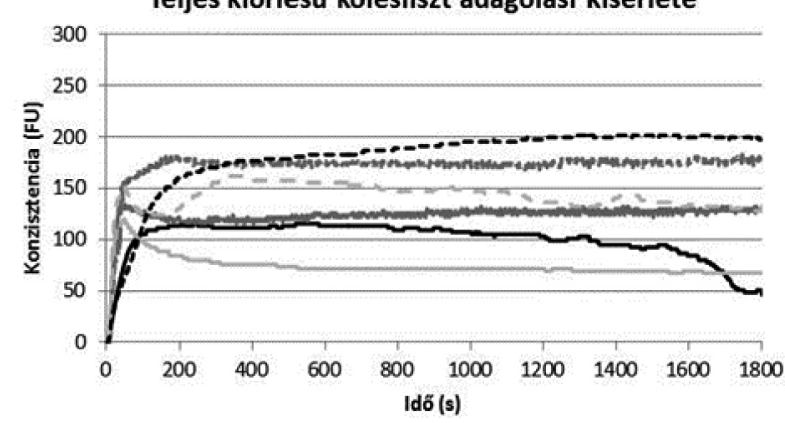

Fehér kölesliszt adagolási kísérlete

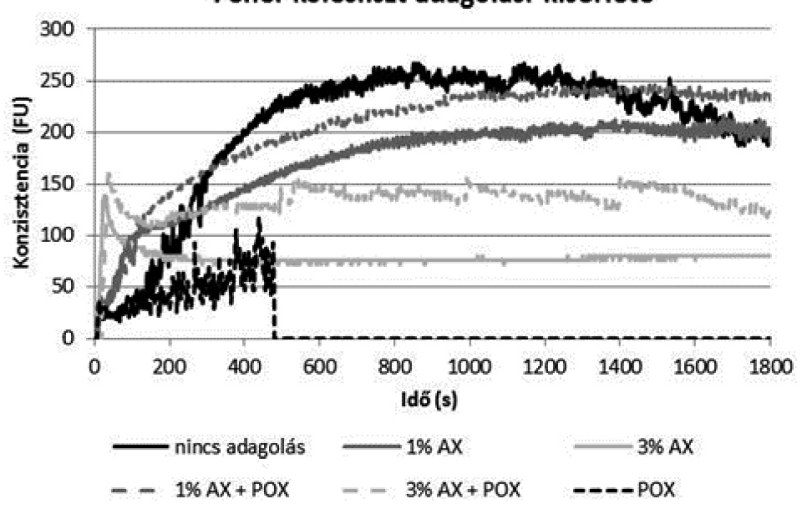

2. ábra. Köleslisztek dagasztási tulajdonságainak alakulása pentozán adagolás (arabinoxilán extraktum, $\mathrm{AX}$ ), piranóz oxidázzal történő enzimes kezelés $(\mathrm{POX})$ és a két hatás kombinálásának $(\mathrm{AX}+\mathrm{POX})$ hatására

Mivel a kölesliszt a sikérhez hasonló szerkezetépítő fehérjéket nem tartalmaz, a tésztamátrix kialakulása és a lisztek között tapasztalható különbségek is másként magyarázhatók. A fehérliszt esetében elsősorban a fehérjék és a keményítő hidratációja során kialakuló viszkózus szerkezet tulajdonságait regisztráljuk. A teljes kiőrlésű mintáknál azonban mind a hidratáció dinamikáját, mind a tésztaszerkezet alakulását a nagyobb fehérjemennyiség mellett a nem keményítő szénhidrátok, pentozánok is jelentősen befolyásolják. Részben ezzel magyarázható a gyorsabb tésztakialakulás és az gyengébb szerkezet is. ${ }^{13}$

\subsection{Alapanyagok reológiai viselkedésének változása AX adagolás és enzimes kezelés hatására}

$\mathrm{Az}$ AX extraktum adagolásának hatása részben függ az alapanyag jellegétől és az adagolás mértékétől. (2. ábra $\mathrm{AX}$ görbék). A teljes őrlemény esetében az 1\%-os adagolás nem okoz kiemelkedő változást a tészta konzisztenciagörbéjének lefutásában. Ugyanakkor a tésztaképződés folyamata valamivel gyorsabb és kicsit erősebb tészta alakul ki. Nagyobb eltérés a stabilitásban mutatkozik, a kialakult tészta konzisztenciája gyakorlatilag a mérés végéig nem változik. Az AX extraktum mennyiségének növelésével gyengébb tészta jön létre, mely valószínúleg az $\mathrm{AX}$ viszkózus tulajdonságot befolyásoló hatásával magyarázható. A fehérliszt esetében az látható, hogy az 1\%-os és a 3\%-os AX adagolás egyaránt gyengíti a tésztaszerkezetet, miközben a tésztakialakulás folyamatára itt is kedvező hatással van, gyorsítja azt. A jelenség magyarázatával jelenleg még adósok vagyunk, ez irányú vizsgálatok jelenleg is folynak. Feltételezhető, hogy ennek hátterében az eltérő szénhidrátösszetétel áll. A kisebb keményítő és a nagyobb szabad AX tartalom eltérő makromolekuláris szerkezet (fehérje-keményítő-pentozán mátrix) kialakulásához vezet, mely jelentős szerepet játszik a tészta felépülésében. Az eredmények azt is sugallják, hogy létezik olyan „optimális” összetétel, mely gluténmentes alapanyagok esetében is viszonylag kedvező tésztamátrix kialakítását teszi lehetővé.

Az eredeti kutatási koncepció, a pentozánhálózat felépítés lehetőségének vizsgálata érdekében nézzük meg, hogyan alakul a tészták reológiai viselkedése az $\mathrm{AX}$ adagolás és a POX enzim együttes alkalmazása során. (2. ábra AX+POX). A válasz viszonylag egyértelmü: minden esetben az enzimkezelés a konzisztencia növekedését okozza a csak adagolt AX-et tartalmazó mintákhoz képest. Természetesen a változás mértéke az alapanyagtól és az AX tartalomtól is függ, azonban a pozitív hatás valamennyi ide tartozó kísérlet esetében egyértelmü. Sőt, a teljes őrleményből készült tészták esetében azt is megfigyelhetjük, hogy az AX adagolás és az enzimkezelés az alapliszténél lényegesen erősebb tésztakonzisztenciát eredményez. Úgy tünik tehát, hogy az eddig elvégzett reológia mérések eredményei tulajdonképpen közvetett módon alátámasztják kutatási programunk alaphipotézisét. A szabad (esetünkben adagolt) AX jelenlétében, enzimkezelés hatására erősebb tésztaszerkezet alakul ki, ami jól magyarázható a pentozánhálózat kiépülésével, melynek feltételezett mechanizmusát az 1. ábrán vázoltuk.

Ugyanakkor a kísérletterv nem lenne teljes, ha egyfajta negatív kontrollként az AX adagolás nélküli enzimhatás vizsgálatát elhagynánk. Ha a lisztekhez csak POX enzimet adagolunk, a liszt típusától függően eltérő hatást regisztrálhatunk. (2. ábra, POX) A teljes örlemény esetében a tésztaképződés folyamata a kezelések nélküli alapmátrixhoz hasonló. Ugyanakkor ebben a kísérletben alakult ki a legerősebb és legstabilabb tésztaszerkezet úgy, hogy a liszt saját, a tésztaszerkezetet gyengítő, többségében kötött nem keményítő szénhidrátjai mellett adagolt, szabad pentozánok is találhatók a rendszerben. Ezzel szemben a fehérlisztnél egy lassú kezdeti hidratációs folyamat után a tésztaszerkezet összeomlása következik be. 
Az AX adagolás nélküli fehérliszt enzimes kezelésénél tapasztalt fontos kérdésre irányítja rá a figyelmet. A szabad pentozánok hiányában mérhető jelentős tésztaerősség és -stabilitás növekedés ugyanis közvetett bizonyíték arra, hogy a tésztaszerkezet alakításában más összetevők is meghatározó szerephez jutnak. Kézenfekvőnek tünik a fehérjék funkciójának tanulmányozása. Ismeretes, hogy oxidatív enzimek, illetve az az enzimreakció során keletkező hidrogénperoxid jelenlétében a fehérjék cisztein, triptofán és tirozin oldalláncai is reakcióképesek. ${ }^{21}$ Oxidációs közegben inter- és intramolekuláris keresztkötések alakulhatnak ki, sőt más, nem fehérje komponens is részt vehet az oxidatív reakcióban. (3. ábra). A molekulán belüli szerkezetváltozás is hatással lehet a fehérjék fizikai-kémiai tulajdonságaira. A kutatás célkitüzése szempontjából azonban az intermolekuláris kötések létrejötte tünik jelentősebbnek. A tészta konzisztenciájának erősödése ugyanis jól magyarázható lenne nagyobb méretü fehérjepolimerek kialakulásával. Ennek igazolása többek között méretkizárásos folyadékkromatográfiás módszer (SE-HPLC) alkalmazásával lehetséges, a méréseket jelenleg végezzük.

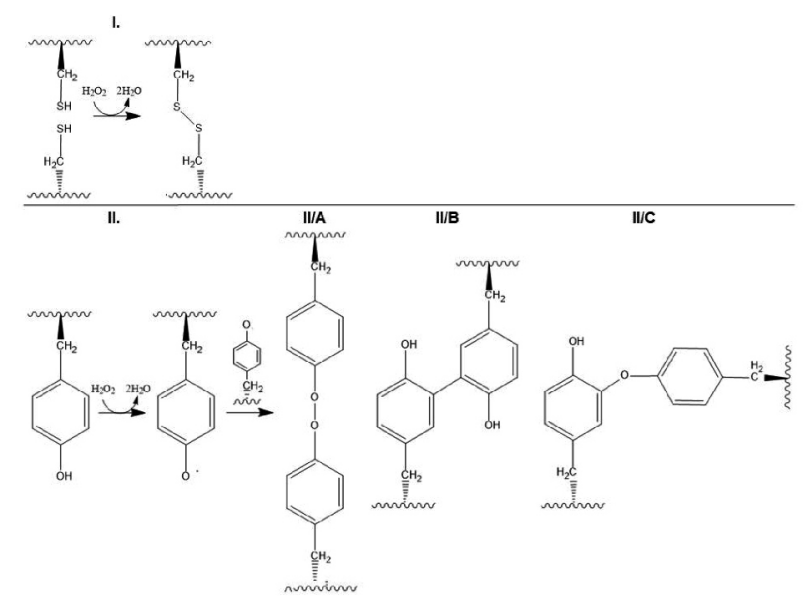

3. ábra Az aminosav oldalláncok oxidációja során kialakuló lehetséges keresztkötések

\section{4. Összegzés}

Munkánkban a gluténmentes alapanyagok táplálkozási és technológiai tulajdonságainak javítási lehetőségeit vizsgáltuk. Célunk volt rostalkotó arabinoxilánok (AX) adagolásával és oxidatív enzimkezeléssel (POX) olyan pentozánhálózat kialakítása, amely legalább részlegesen képes a sikérfehérjék szerkezetalakító szerepének helyettesítésére. Az adagolások és az enzimkezelések hatását kölesőrleményekből vízadagolással kialakított tészta modellmátrixok komplex reológiai tulajdonságainak mérésével követtük. Eredményeink megerősítették, hogy lehetséges az alkalmazott kezelésekkel a tésztakonzisztencia célzott módosítása. Azonban a reológiai tulajdonságok változása csak részben magyarázható az $\mathrm{AX}$ molekulák között kialakuló keresztkötések létrejöttével, pentozán makropolimerek képződésével. Kísérletesen igazoltuk, hogy az enzimkezelés AX molekulák hiányában is a tészták reológiai tulajdonságainak változásához, konzisztenciájának erősödéséhez vezet. Lehetséges magyarázat a fehérjék oxidálható oldalláncai között kialakuló keresztkötések létrejötte, ezzel a fehérjeszerkezet megváltozása. Az AX adagolás és az enzimkezelés hatása tehát összetett folyamatok eredője, függ a mátrix összetételétől, a jelenlévő makromolekulák (pentozánok, keményítő, fehérjék) jellemzőitől, illetve a szubsztrátok mennyiségétől is. A tapasztalt jelenségek megértése a gluténmentes termékfejlesztés egyik kulcskérdése. A változások okainak molekuláris szintủ feltárása kutatómunkánk folytatásának legfontosabb célkitüzése.

\section{Köszönetnyilvánítás}

Munkánk kapcsolódik a "Gluténmentes tészta minőségének javítása hemicellulóz hálózat kialakításával” (OTKA-ANN 114554) valamint a „Módosított szénhidrátrendszereken alapuló gluténmentes tészta és végtermék modellek szerkezeti, reológiai és funkcionális tulajdonságainak vizsgálata" (TÉT_15-1-2016-0066) címü projektek szakmai céljainak megvalósításához. 


\section{Hivatkozások}

1. Mustalahti, K.; Catassi, C.; Reunanen, A.; Fabiani, E.; Heier, M.; Mcmillan, S.; Murray, L.; Metzger, M.; Gasparin, M.; Bravi, E.; Ki, M. M. Ä. Ann. Med. 2010, 42, 587-595. https://doi.org/10.3109/07853890.2010.505931

2. Catassi, C.; Kryszak, D.; Bhatti, B.; Sturgeon, C.; Helzlsouer, K.; Clipp, S. L.; Gelfond, D.; Puppa, E.; Sferruzza, A.; Fasano, A. Ann. Med. 2010, 42, 530-538. https://doi.org/10.3109/07853890.2010.514285

3. Shewry, P. R. J. Exp. Bot. 2009, 60 (6), 1537-1553. https://doi.org/10.1093/jxb/erp058

4. Tömösközi, S.; Békés, F. In Encyclopedia of Food and Health; Caballero, B., Finglas, P., Toldrá, F., Eds; Academic Press: Oxford, 2016; pp 490-499. https://doi.org/10.1016/B978-0-12-384947-2.00086-6

5. Alvarez-Jubete, L.; Arendt, E. K.; Gallagher, E. Trends Food Sci. Technol. 2010, 21 (2), 106-113. https://doi.org/10.1016/j.tifs.2009.10.014

6. Bagdi, A.; Balázs, G.; Schmidt, J.; Szatmári, M.; Schoenlechner, R.; Berghofer, E.; Tömösközi, S. Acta Aliment. 2011, 40 (1), 128-141. https://doi.org/10.1556/AAlim.40.2011.1.15

7. Schoenlechner, R.; Wendner, M.; Siebenhandl-ehn, S.; Berghofer, E. J. Cereal Sci. 2010, 52 (3), 475-479. https://doi.org/10.1016/j.jcs.2010.08.001

8. Padalino, L.; Conte, A.; Del Nobile, M. Foods 2016, 5 (4), 87. https://doi.org/10.3390/foods5040087

9. Pellegrini, N.; Agostoni, C. J. Sci. Food Agric. 2015, 95 , 2380-2385. https://doi.org/10.1002/jsfa.7101

10. Haros, C. M.; Schoenlechner, R. Pseudocereals: Chemistry and Technology; Wiley-Blackwell, 2017. ISBN: 978-1-118-93828-7 https://doi.org/10.1002/9781118938256

11. Matos, M. E.; Rosell, C. M. J. Sci. Food Agric. 2014, 95 (4), 653-661. https://doi.org/10.1002/jsfa.6732
12. Padalino, L.; Conte, A.; Del Nobile, M. A. Foods 2016, 5 (4), 87. https://doi.org/10.3390/foods5040087

13. Denli, E.; Ercan, R. Eur. Food Res. Technol. 2001, 212, 374-376. https://doi.org/10.1007/s002170000281

14. Bagdi, A.; Tömösközi, S.; Nyström, L. Food Hydrocoll. 2017, 63, 219-225. https://doi.org/10.1016/j.foodhyd.2016.08.045

15. Sternemalm, E.; Heikkinen, S.; Tenkanen, M.; Gatenholm, P. Biomacromolecules 2008, 9, 2042-2047. https://doi.org/10.1021/bm800290m

16. Mansberger, A.; D’Amico, S.; Novalin, S.; Schmidt, J.; Tömösközi, S.; Berghofer, E.; Schoenlechner, R. Food Hydrocoll. 2014, 35, 606-612. https://doi.org/10.1016/j.foodhyd.2013.08.010

17. Bender, D.; Schmatz, M.; Novalin, S.; Nemeth, R.; Chrysanthopoulou, F.; Tömösközi, S.; Török, K.; Schoenlechner, R.; Amico, S. D. Chem. Biol. Technol. Agric. 2017, 4 (14), 1-8. https://doi.org/10.1186/s40538-017-0096-6

18. Vojta, E. Masterthesis, University of Natural Resources and Life Sciences Vienna, 2015

19. Gebruers, K.; Courtin, C. M.; Delcour, J. A. In HEALTHGRAIN Methods: Analysis of Bioactive Components in Small Grain Cereals; Shewry, P., Ward, L. J., Eds; AACC International, Inc.: St. Paul, Minnesota, 2009; pp 177-189. ISBN : 9781891127700 https://doi.org/10.1016/B978-1-891127-70-0.50017-0

20. Békés. F.; Lukow, O.; Uthayakumaran, S.; Mann, G. In Wheat Gluten Protein Analysis; Shewry P. R., Lookhart G., Eds; AACC International, Inc.: St. Paul, Minnesota, 2000; pp 173-198. ISBN: 978-1-891127-32-8

21. Mattinen, M-J.; Hellman, M.; Permi, P.; Autio, K.; Kalkkinen, N.; Buchert. J. J. Agric. Food Chem., 2006, 54 (23), pp 8883-8890. https://doi.org/10.1021/jf062397h

\section{Development of nutritional and technological quality of gluten free products}

Celiac disease is an autoimmune mediated disorder of the digestive system which affect mainly the small intestine causing malabsorption. Therefore, it can lead to decreased nutrient utilization and even serious undernourishment. According to international scientific surveys celiac disease occurs in approximately $1 \%$ of the population worldwide. This ratio can be different by geographical areas and countries. ${ }^{1,2}$ Storage proteins (gluten proteins) of specific cereals (wheat, rye, barley) are responsible for the development of the disorder and it can be treated with the application of a strict gluten-free diet, only. ${ }^{3}$ The most important raw materials of gluten-free food are maize and rice but nowadays the increased utilisation of other alternative cereals (millet, sorghum, oat, etc.) and pseudocereals (amaranth, buckwheat, quinoa) can be observed thanks to their higher nutritional value and the changes in consumer demands. ${ }^{4,5,6}$

Gluten proteins - especially in case of wheat - influence basically the technological behavior of dough made from cereal meals and determine the quality of the gluten containing food (pasta, bakery products, etc.). Protein fractions of gluten (glutelins and prolamins) and starch granules are able to form a characteristic, viscoelastic protein-starch matrix due to water addition (hydration) and mechanical work (kneading). These are explaining the unique properties of the end products made from wheat flour. ${ }^{7}$ The storage proteins of other cereals does not or partly dispose of structure forming properties.

Although, for example, rye contains gluten proteins and bakery products can be produced from its flours, but beside proteins, dietary fiber components, like the health promoting pentosans have also an important role in structure forming of the end product. The technological properties of gluten-free materials differ significantly and in general weak, less elastic, sticky dough sructures are formed from their meals when water is added having poor baking performance. ${ }^{8}$ Beside the different technological behavior the gluten-free materials and products have diverse nutritional value too. Especially in case of cheaper food products the consumption and distribution of hulled products and refined meals were spread to ensure homogeneity, acceptable technological properties and adequate sensory properties. The quantity of 
proteins, minerals, dietary fibers, vitamins and bioactive compounds, etc. may be inferior to the composition of their wheat-based counterparts in most of these products. ${ }^{9,10}$

Currently the general methods of improving the physicochemical, rheological and textural properties are the use of appropriate additives and excipients (e.g. hydrocolloids, emulsifiers, protein isolates, modificated starches, etc.), different techniques (sourdough fermentation, enzymatic or overpressure treatments) or their combination. ${ }^{10,11}$ Possible ways of increasing nutritional value are the supplementation of the raw materials (e.g. legumes and cereals), the utilization of higher fiber content or even wholemeal meals or the addition of limiting components. However, these latter solutions influence significantly and in case of wholemeal products especially adversely the technological and sensory properties of the products. ${ }^{11,12}$ Therefore the aim of this work was finding solutions for the simultaneous improvement of nutritional value and technological properties of gluten-free products. The nutritional advantages of wholemeal or higher fiber content milling fractions are the higher fiber, lipid, mineral and bioactive compound content. Cereal fibers include high amount of non-starch polysaccharides like pentosans whose main representatives are the arabinoxylans (AX). AX molecules are branching heteropolymers in which a backbone consists of $\beta$-D-Xylopyranose monomers substituated with $\alpha$-L-Arabinofuranosyl residues. The polymers contain ferulic acid in specific ratio depending on the origin, which can be oxidized forming cross-links. The $\mathrm{A} / \mathrm{X}$ ratio and the number of cross-links determine the molecular weight and physicochemical properties of AX molecules fundamentally. ${ }^{13}$ Consequently the size and the properties of AX molecules can be influenced targeted by changing the oxidation state using chemical oxidation agents or enzymes. Regarding food security aspects the application of enzyme treatment (using oxidases, laccases) is recommended. ${ }^{14}$ The advantage of enzymes is that with properly selected and modified microorganism (yeast) the enzyme catalyzed reactions can be built into the fermentation process (leavening, sourdough technology). Theoretically with well-regulated oxidation and increasing the number of ferulic acid cross-links even such a carbohydrate network (Figure 1) can be formed which may be able to at least partially substitute the missing gluten network in gluten-free products and to improve the rheological properties of hydrated dough matrices.

In our work the modification options of viscoelastic properties of gluten-free dough matrices was investigated according to the train of thought expounded above. The effect of the pentosan content, the enzyme treatment and their combination on the rheological properties of gluten-free dough systems were examined. 